Volume 2, Number 1, 2016

\title{
Investigation of Differential Pressure Flowmeters Accuracy in Pulsating Flows
}

\author{
Roman Fedoryshyn", Fedir Matiko, Ihor Kostyk, Yevhen Pistun \\ Lviv Polytechnic National University, 12, S. Bandery St., Lviv, 79013, Ukraine
}

Received: November 16, 2015. Revised: March 09, 2016. Accepted: December 23, 2016

(C) 2016 The Authors. Published by Lviv Polytechnic National University.

\begin{abstract}
This work deals with the investigation of influence of flow pulsation on the accuracy of gas flowrate and volume measurement by means of the differential pressure flowmeters. Experimental studies of the step response curves of an impulse line with a pressure transducer (PT) were carried out with application of a high-frequency analog-to-digital converter of the pressure signal in the PT chamber. Mathematical model of an impulse line with a PT was built. This model provides simulation and investigation of the transient processes with high accuracy. The influence of the impulse line design (length, diameter) on the step response curves and on the frequency response curves as well as on the resonant frequency of the oscillating system (an impulse line with a PT chamber) was studied. The systematic errors of flowrate and volume measurement due to the resonance in the impulse lines which was caused by flow pulsation were simulated and studied for an acting differential pressure natural gas metering system. On the basis of the calculation results, it was defined that amplification of the amplitude of the oscillating signal of the differential pressure due to the resonance may lead to a negative systematic error of gas volume measurement. The systematic errors of gas flowrate and volume measurement caused by the flow pulsation can be reduced by choosing the correct design of the impulse lines in order to avoid the resonance.
\end{abstract}

Keywords: flowmeter; flow pulsation; measurement; pressure transducer; natural gas.

\section{Introduction}

The accuracy of flowrate measurement is a very important issue today especially for fluid energy carriers flowrate and volume measurement. The differential pressure method is one of the most widespread methods for flowrate measurement. The flowmeters based on this method are simple in construction and mounting. The standard differential pressure devices are available for application at the pipes with diameters of 50 to $1000 \mathrm{~mm}$. However, flow pulsations may take place in the measuring sections of the pipes. These pulsations can be caused by the following factors: reciprocal movement of pistons of compressors and pumps; vibration of the pipe and of the equipment installed on it; periodical operation (triggering) and oscillation of the regulating equipment (ball valves, gate valves etc.); flow swirl on the elements installed in the pipe (thermometer well, filter etc.); flow swirl at the tees; geometrical configuration of the pipeline etc. These factors may lead to a negative impact on the accuracy of flowrate and volume measurement since they may cause the additional errors of measurement.

The main sources of the additional errors of flowrate measurement by means of the differential pressure devices during the flow pulsations are as follows: the square root dependence between the flowrate and the differential pressure; the local acceleration; the acoustic phenomena in the pipe; the dynamic characteristics of the impulse lines.

If the gas-dynamical resistances of the impulse lines between the orifice plate and the differential pressure transducer are different or non-linear then it is also a source of additional errors of gas flowrate measurement when flow pulsations take place. The medium in the impulse lines is moving back and forth continuously during flow pulsations. That is why the non-linear resistances lead to distortion of the transferred differential pressure signal (the more unsymmetrical pulsations the bigger the distortion).

\footnotetext{
*Corresponding author. Email address: romanfedoryshyn@yahoo.com
} 
Even if there are no non-linear resistances in the impulse lines, the latter may be a source of the error of measurement. Based on the experimental and theoretical study $[1,2]$ it was defined that an impulse line together with the chamber of a pressure transducer is an oscillating system where resonance may take place. The resonance in the impulse line leads to the additional error of flowrate and volume measurement which is demonstrated in this work.

The influence of the impulse line design on the error of flowrate measurement by means of the differential pressure flowmeters is considered in $[3,4]$. There is a qualitative description of the influence in these works and there are general recommendations on choosing the design of the impulse lines for measurement of flowrate of a pulsating flow. However there is no quantitative assessment of this influence.

The Standard [5] deals with the measurement of flowrate of a pulsating flow. There is a technique for calculating the additional error of volume measurement caused by the flow pulsation in this Standard. However there is no information in [5] on the design of the impulse lines and its influence on the additional error of measurement.

The goal of this work is to present the results of the experimental study of the step response curves of the impulse lines with the pressure transducer, to present the developed mathematical model of the impulse line and to study the influence of flow pulsations on the measured values of the pressure, the differential pressure, the flowrate and the volume of natural gas in an acting natural gas metering system based on the differential pressure method.

\section{Experimental study}

The experimental study of the step response curves of the impulse lines with the pressure transducer was carried out by means of a rig where air was used as a working gas. The diagram of the rig is presented in Fig. 1. There were the following main devices and components in the rig:

- impulse line with the internal diameter of $4 \mathrm{~mm}$ and with the following three different lengths: $2.1 \mathrm{~m} ; 4.2 \mathrm{~m} ; 6.3 \mathrm{~m}$;

- electro-magnetic valve ZGRCH6UP, Bürkert, (1-4 in Fig. 1);

- pressure transducer PPS.3-PN (overpressure), Techprylad, (1-5 in Fig. 1), the upper limit of measurement is $10 \mathrm{kPa}$, the main error of measurement is $0.15 \%$;

- differential pressure transducer Sitrans P DSIII (applied for pressure measurement), Siemens, (1-1 in Fig. 1), the upper limit of measurement is $10 \mathrm{kPa}$, the main error of measurement is $0.15 \%$;

- analog-to-digital converter NI USB-6009, National Instruments, (1-6 in Fig. 1), the resolution is 12 bit, the sampling frequency is $48 \mathrm{kHz}$;

- compressor UK25-16M with the maximum output pressure of $343.2 \mathrm{kPa}$;

- pressure stabilizer SAD-305 (1-3 in Fig. 1);

- vessel ( $\left.\mathrm{D}=180 \mathrm{~mm}, \mathrm{H}=310 \mathrm{~mm}, \mathrm{~V}=0.0079 \mathrm{~m}^{3}\right)$.

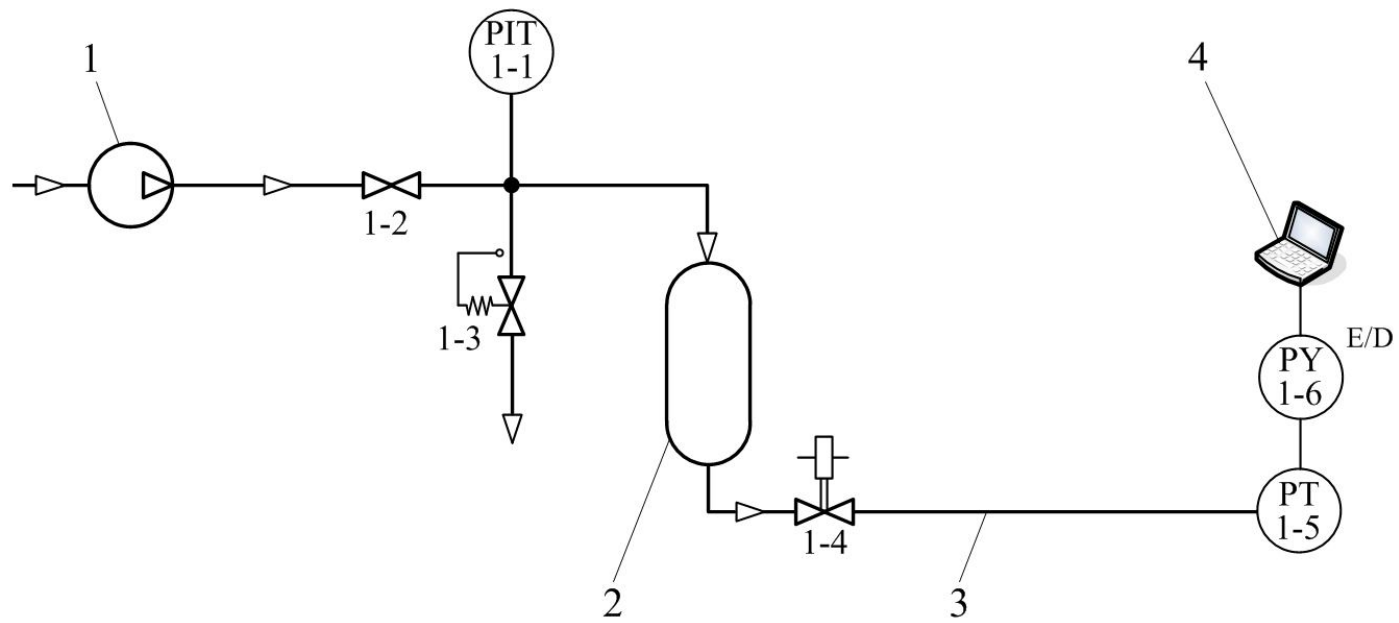

Fig. 1. Functional diagram of the experimental rig: 1 - compressor; 2 - vessel; 3 - impulse line; 4 - PC 
The pressure transducer (PT) PPS.3-PN of Techprylad Company (Lviv, Ukraine) was applied for obtaining the transient processes of pressure variation at the end of the impulse line (IL). This PT was chosen because there is an analog electric diagram in it without a built-in filter or digital processing of the output signal and it can be applied for pressure measurement in high speed varying processes.

The aim of the experimental study was to obtain and record the transient processes at the output of the PT (1-5) after a step change of pressure was given to the input of the IL (3). The pressure in the system was created by means of the compressor (1). The valve (1-2) and the stabilizer (1-3) were used to set the desired value of the pressure in the system. This pressure was measured by means of the transducer (1-1). The vessel (2) was installed to stabilize the pressure in the system and to provide rapid change of the pressure at the input of the IL. The internal volume of the vessel was 100 times bigger than the internal volume of the IL together with the volume of chamber of the PT.

After opening the electro-magnetic valve (1-4), the air moved from the vessel to the input of the IL. This is how the step change of pressure was created. At the same time the change of pressure in the vessel was insignificant. The response signal from the output of the PT was given to the input of the analog-to-digital converter (ADC). The digital output signal from ADC (1-6) was processes by the PC with a corresponding software (4). Since the input signal of ADC should have been the voltage of 0-10 V, the output signal of PT (electric current 4-20 mA) was transformed to the voltage by means of the resistor bank (see Fig. 2) with the adjusted resistance of $500 \mathrm{Ohm}$.

Three series of tests were carried out for the ILs of different lengths $(2.1 \mathrm{~m} ; 4.2 \mathrm{~m} ; 6.3 \mathrm{~m})$. There were 10 tests in each series for the IL of a particular length, i.e. 10 transient processes were obtained for the same step change of the pressure for each IL. The tests were carried out in the following way:

1) The electro-magnetic valve (1-4) was opened and the pressure in the whole system (vessel and the IL) was set to $4 \mathrm{kPa}$.

2) The electro-magnetic valve was closed.

3) New value of the pressure $(8 \mathrm{kPa})$ was set in the vessel by means of the pressure stabilizer (1-3) .

4) The electro-magnetic valve was opened abruptly. The transient process in the chamber of the PT took place and the electric output signal of PT (U) was recorded.

5) To carry out the next test the pressure in the whole system was reduced down to $4 \mathrm{kPa}$ and steps $2-4$ were accomplished.

The value of the step change of pressure at the input of the IL in each test was $4 \mathrm{kPa}$.

As the result of processing and averaging 10 transient processes for each IL, the averaged step response curves were obtained (see Fig. 3 and Fig. 4). The values of the averaged curves for each specific moment of time were obtained as a mean arithmetic value of the 10 transient processes in the specific moment of time. This averaging was done in order to eliminate the random deviations that may have occurred during the test.

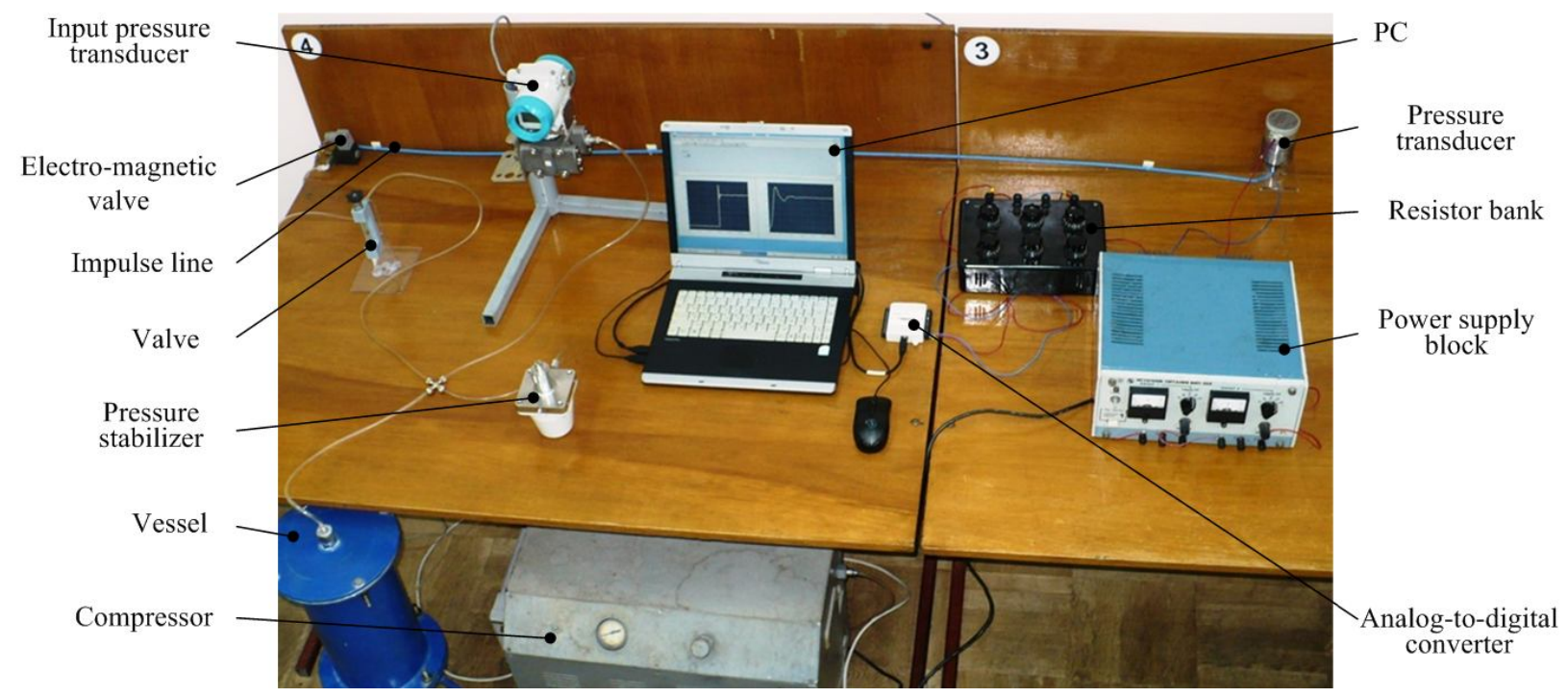

Fig. 2. Picture of the experimental rig 


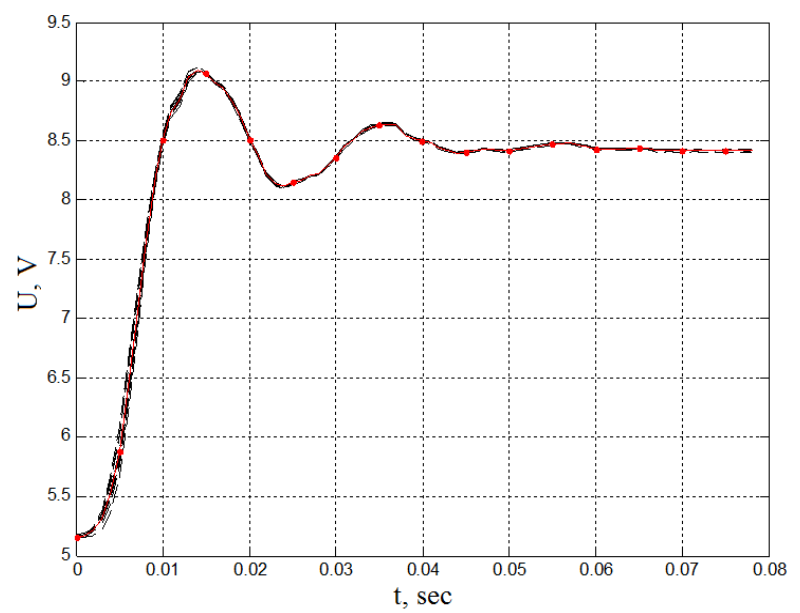

Fig. 3. Step response curves at the output of the PT for the IL with the length of $4.2 \mathrm{~m}$ :

“-_" experimental curves, “-•-." averaged curve

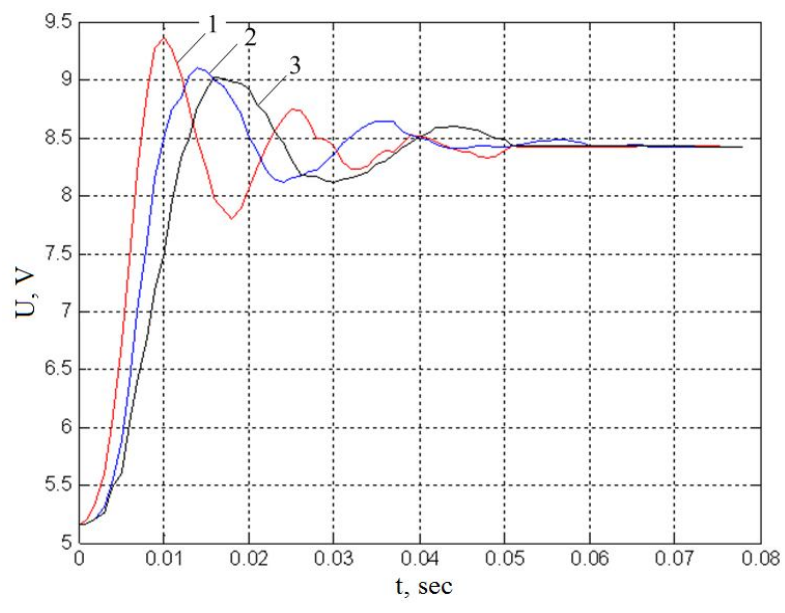

Fig. 4. Averaged step response curves for the ILs of the following lengths:

$1-2.1 \mathrm{~m} ; 2-4.2 \mathrm{~m} ; 3-6.3 \mathrm{~m}$

As we can see from Fig. 3, the same transient process took place in every test during the whole series of 10 tests. It means that the repeatability of the experimental measurements was high. The maximum relative deviation of the experimental values from the averaged values does not exceed $4 \%$. It can be seen from Fig. 4 that for a longer IL the duration of the transient process is longer and the first amplitude of the oscillations is smaller which is explained by the increase of the volume of the IL.

Based on the results of the experimental tests we can see that if a step change of pressure is given to the input of an IL the oscillating transient process takes place at the output of the PT. It means that the IL together with the PT is an oscillating system where resonance may take place (like in any oscillating system). The resonance may lead to negative consequences during the measurement process and may cause the additional systematic errors of measurement.

\section{Mathematical model}

In order to develop the mathematical model of the IL, it was considered that the pressure signal from the pipe (or from the carrier ring of an orifice plate) was transferred by means of the IL to the chamber of the PT (or the differential pressure transducer (DPT)) and there was a connecting nipple (throttle) between them. The diagram of the IL for development of its mathematical model is presented in Fig. 5.

The internal diameter of the connecting nipple (throttle) is smaller than the internal diameter of the IL. That is why the nipple was considered as a cylindrical throttle. The following assumptions were made during the development of the mathematical model:

- the temperature of the gas in the IL is the same along the IL and does not vary in time;

- the volume of the chamber of PT is constant;

- the molar mass and the compressibility factor of the gas are constant within the time of investigation of the pressure pulsations.

The mathematical model was developed based on the following equations and formulae:

- the modified Mendeleev-Clapeyron equation of state for defining the mass of gas in the chamber of the PT;

- the Newton's second law for the description of the gas movement in the IL;

- the Darcy-Weisbach equation for defining the pressure at the input of the nipple;

- other equations of the classical fluid dynamics theory.

When there is pressure pulsation at the input of the IL, the gas is moving alternately in one direction and in the other one along the IL. The velocity of the gas in the IL varies from its maximum value to zero and vice versa. It leads to variation of the regime of the gas flow in the IL from turbulent to laminar and vice versa. Under such conditions, 


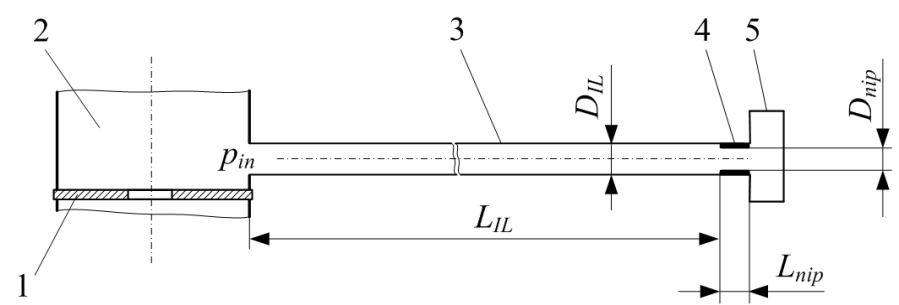

Fig. 5. Diagram of the IL for development of its mathematical model: 1 - orifice plate; 2 - pipe; 3 -impulse line; 4 - nipple; 5 - chamber of PT

it is appropriate to apply the Darcy-Weisbach equation for defining the pressure difference between the input and the output of the IL. This equation provides the possibility to describe both turbulent and laminar regime of the flow, since the dependence of the pressure difference on the velocity of the flow varies depending on the formula for expressing the coefficient of hydraulic friction $(\lambda)$. If we take the formula for the laminar regime $(\lambda=64 / R e)$ the Darcy-Weisbach equation will be transformed to the Poiseuille equation for the laminar regime of flow [6].

In order to take into account the dynamic characteristics of the PT, one more equation was introduced into the mathematical model. It was a differential equation for describing the relation between the output electric signal and the input pressure signal of the PT. The values of the coefficients in this equation were defined experimentally by means of the rig presented in Fig. 2.

After bringing together all the equations and making all the necessary mathematical transformations the mathematical model of the IL with the PT can be presented by the following system of differential equations:

$$
\left\{\begin{array}{l}
A \frac{d p_{c h}}{d t}=Q \cdot \rho \\
k_{1} \cdot \frac{d Q}{d t}+k_{2} \cdot Q^{2}=p_{i n}-p_{c h} \\
T_{P T} \cdot \frac{d U}{d t}+U=k_{P T} \cdot p_{c h},
\end{array}\right.
$$

where $A, k_{1}, k_{2}$ are coefficients that are calculated according to the formulae (2)-(4); $p_{c h}$ is the pressure in the chamber of PT, Pa; $Q$ is the gas flowrate in the IL (in operating conditions), $\mathrm{m}^{3} / \mathrm{sec} ; \rho$ is the gas density in the IL (in operating conditions), $\mathrm{kg} / \mathrm{m}^{3} ; p_{i n}$ is the pressure at the input of the IL, Pa; $U$ is the voltage at the output of the PT, $\mathrm{V} ; T_{P T}$ is the time constant of the PT, sec; $k_{P T}$ is the transfer coefficient of the PT, V/Pa.

The coefficients $A, k_{1}, k_{2}$ are calculated by the following formulae:

$$
\begin{gathered}
A=\frac{V_{c h} \cdot M}{z \cdot R \cdot T}, \\
k_{1}=\frac{\rho \cdot L_{I L}}{S_{I L}}, \\
k_{2}=\frac{\lambda \cdot \frac{\rho}{2} \cdot\left(\frac{L_{n i p}}{D_{n i p}}+\frac{L_{I L}}{D_{I L}}\right)}{S_{I L}{ }^{2}},
\end{gathered}
$$

where $V_{c h}$ is the volume of the chamber of PT, $\mathrm{m}^{3} ; M$ is the molar mass of gas, $\mathrm{kg} / \mathrm{kmol} ; z$ is the compressibility factor of gas; $R$ is the universal gas constant, $\mathrm{R}=8314.51 \mathrm{~J} /(\mathrm{kmol} \cdot \mathrm{K}) ; T$ is the absolute temperature of gas, $\mathrm{K} ; L_{I L}$ is the length of the IL, $\mathrm{m} ; D_{I L}$ is the internal diameter of the IL, $\mathrm{m} ; S_{I L}$ is the area of the cross-section of the IL, $\mathrm{m}^{2}$ $\left(S_{I L}=\pi \cdot D_{I L}^{2} / 4\right) ; L_{n i p}$ is the length of the nipple, $\mathrm{m} ; D_{n i p}$ is the internal diameter of the nipple, $\mathrm{m}$.

The constant coefficients $A, k_{1}, k_{2}$ were calculated for the gas parameters in the IL at the initial conditions ( $p_{c h 0}$, $Q_{0}$ ). The experimental values of the time constant and transfer coefficient of the PT were $T_{P T}=0.00425 \mathrm{sec}$; $k_{P T}=0.0008 \mathrm{~V} / \mathrm{Pa}$. The gas compressibility factor was calculated using the US VNIC SMV method presented in GOST 30319.2-96 Standard [7]. The hydraulic friction coefficient $\lambda$ was calculated using the equations presented in [8] (the type of equation depends on the value of the Reynolds number). The system of differential equations (1) was solved using the numerical methods by means of MATLAB software. 
Step response curves were simulated and studied using the developed mathematical model of the IL with the PT (1). The simulated curves were compared to the experimental averaged curves (see Fig. 6).

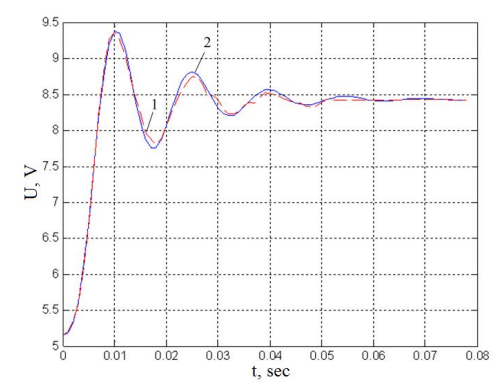

a

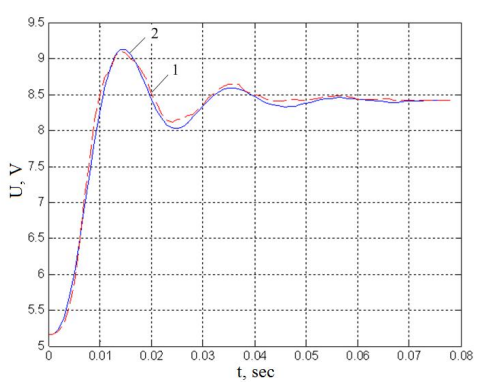

b

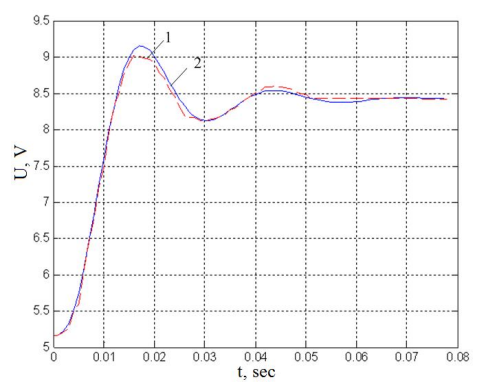

c

Fig. 6. The experimental (1) and the simulated (2) step response curves:

$$
a-L_{I L}=2.1 \mathrm{~m} ; b-L_{I L}=4.2 \mathrm{~m} ; c-L_{I L}=6.3 \mathrm{~m}
$$

Based on the obtained transient processes the relative deviation of the simulated values from the experimental ones was calculated with taking into account the averaging of the experimental step response curves. The maximum relative deviation of the simulated curves from the experimental ones is $6.4 \%$. Thus we conclude that the developed mathematical model is adequate and can be applied for studying the characteristics of the ILs with the PTs (or DPTs).

\section{Frequency response of the impulse line}

In order to assess the influence of the IL characteristics on the measured values of pressure when pulsations are present the resonant frequencies were calculated (see Table 1) and the frequency response curves were built (see Fig. 7) for ILs of various designs (diameter and length). These calculations were made using the mathematical model derived by linearization of the system of equations (1) for natural gas as a working gas (with the parameters presented in Table 2).

Table 1. Resonant frequencies of impulse lines $\left(f_{\text {res }}, \mathrm{Hz}\right)$

\begin{tabular}{|c|c|c|c|c|c|c|}
\hline & \multicolumn{6}{|c|}{$L_{I L}, \mathrm{~m}$} \\
\hline$D_{I L}, \mathrm{~mm}$ & 1 & 4 & 7 & 10 & 13 & 16 \\
\hline 4 & 21.3 & 10.6 & 8.0 & 6.7 & "5.8 & (5.3 \\
\hline 6 & 31.9 & 15.9 & 12.1 & 10.1 & 8.8 & 8.0 \\
\hline 8 & 42.5 & 21.3 & 16.1 & 13.5 & 11.8 & 10.6 \\
\hline 10 & 53.2 & 26.6 & 20.1 & 16.8 & 14.7 & 13.3 \\
\hline 12 & 63.8 & 31.9 & 24.1 & 20.2 & 17.7 & 16.0 \\
\hline
\end{tabular}

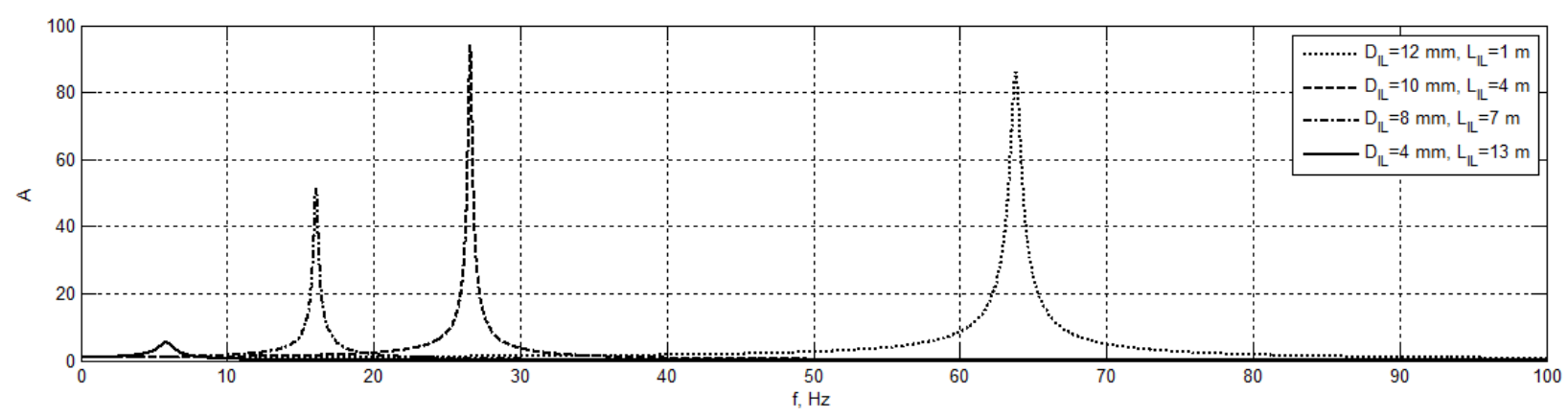

Fig. 7. Frequency response curves of impulse lines

We can see from Table 1 that increase of the IL length leads to decrease of the resonant frequency. And increase of the IL diameter leads to the opposite effect, i.e. increase of the resonant frequency.

The flow pulsations in the pipe according to [5] are divided into the following three groups:

- low-frequency pulsations (with the frequency range from $10^{-4}$ to $0.5 \mathrm{~Hz}$ );

- medium-frequency pulsations (with the frequency range from 0.5 to $30 \mathrm{~Hz}$ ); 
- high-frequency pulsations (with the frequency more than $30 \mathrm{~Hz}$ ).

Based on the calculation results (Table 1 and Fig. 7), we can conclude that for the low-frequency and mediumfrequency pulsations it is better to apply the ILs of a small length and a big diameter. In this case the signal in the PT chamber will repeat the signal at the input of the IL. And for the high-frequency pulsations it is better to apply the ILs of a big length and a small diameter. This way the resonance will be avoided and the high-frequency signal will be filtered.

\section{Influence of flow pulsations on the flowrate and the volume}

To study the influence of flow pulsations on the measured values of flowrate and volume, a simulation was made for an acting natural gas metering system based on the differential pressure method with the parameters presented in Table 2. The primary device in the system was an orifice plate with corner pressure tappings. The gas pressure in the pipe and the differential pressure across the orifice plate were measured by means of a multi-parameter pressure / differential pressure transducer.

There was a big noise around the metering system which might have been caused by the pressure pulsations generated by not complete opening of the gate valve. The gate valve was the first fitting installed at the distance of $10 \mathrm{~m}$ upstream of the orifice plate. The noise could have meant that there were medium- and high-frequency pulsations since the frequency range of the sound waves perceived by a human ear is from 16 to $20 \bullet 10^{3} \mathrm{~Hz}$.

To simulate the measured values of the pressure and the differential pressure, the developed mathematical model of the IL with the PT (1) was applied. The simulation of the differential pressure was made for the case when the source of pulsations was located upstream of the orifice plate.

The ILs in the metering system were $10 \mathrm{~m}$ long and $8 \mathrm{~mm}$ in diameter. The resonant frequency of such ILs is 13.5 Hz (see Table 1). The simulation was made for pressure oscillations with the frequency of $10 \mathrm{~Hz}$ and the amplitude of $5 \mathrm{kPa}$ which is equal to $20 \%$ of the differential pressure $(\Delta p=25 \mathrm{kPa})$ at the average flowrate. Such a signal corresponds to the pulsating regime of gas flow in the pipe. The relative amplitude of the pressure oscillations was 0.014 and the relative standard deviation was 0.01 . The relative amplitude of the differential pressure oscillations was 0.2 and the relative standard deviation was 0.141 . The signal of pressure oscillations was supplied to the input of the mathematical model of the IL with the PT and the resonance phenomenon was simulated. Additionally the signals of the pressure and the differential pressure oscillations after the filtration by means of a filter with the time constant of $0.1 \mathrm{sec}$ were simulated. The results of simulation are presented in Fig. 8 and Fig. 9.

Table 2. Main parameters of the natural gas metering system

\begin{tabular}{|l|c|c|}
\hline \multicolumn{1}{|c|}{ Name of the parameter } & Units & Value \\
\hline \hline Absolute pressure of natural gas & $\mathrm{kPa}$ & 350 \\
\hline Temperature of natural gas & ${ }^{\circ} \mathrm{C}$ & +5.6 \\
\hline Density of natural gas at standard conditions & $\mathrm{kg} / \mathrm{m}^{3}$ & 0.717 \\
\hline Content of nitrogen in natural gas & $\%$ & 0.742 \\
\hline Content of carbon dioxide in natural gas & $\%$ & 0,084 \\
\hline Diameter of orifice plate opening at the temperature of $20^{\circ} \mathrm{C}$ & $\mathrm{mm}$ & 107.525 \\
\hline Internal diameter of pipe at the temperature of $20^{\circ} \mathrm{C}$ & $\mathrm{mm}$ & 407.94 \\
\hline Maximum differential pressure across the orifice plate & $\mathrm{kPa}$ & 63 \\
\hline Differential pressure at the average flowrate & $\mathrm{kPa}$ & 25 \\
\hline Maximum flowrate of natural gas reduced to standard conditions & $\mathrm{m}^{3} / \mathrm{h}$ & 14939 \\
\hline Average flowrate of natural gas reduced to standard conditions & $\mathrm{m}^{3} / \mathrm{h}$ & 9713.3 \\
\hline
\end{tabular}

We can see from the simulation results that the amplitude of the pressure/differential pressure oscillations $(5 \mathrm{kPa})$ is amplified due to the resonance phenomenon in the ILs. The amplitude of the oscillations in the chambers of the DPT is $8.87 \mathrm{kPa}$. The amplitude of the filtered signal is $1.4 \mathrm{kPa}$. The phase shift of the oscillations in the chambers of the DPT relatively to the oscillations in the carrier rings of the orifice plate is $0.3 \mathrm{msec}$. And the phase shift of the filtered signal oscillations relatively to the oscillations in the carrier rings of the orifice plate is $23 \mathrm{msec}$.

Based on the simulated values of the pressure and the differential pressure (in the carrier rings of the orifice plate, in the chambers of the DPT, filtered signals) the corresponding values of flowrate were calculated. The selected points of the pressure and the differential pressure are designated by markers in Fig. 8 and Fig. 9. The values of the flowrate were calculated by means of "Raskhod-RU" software for computer aided design of the differential pressure flowmeters [9]. The calculation results are presented in Table 3 and in Fig. 10. 


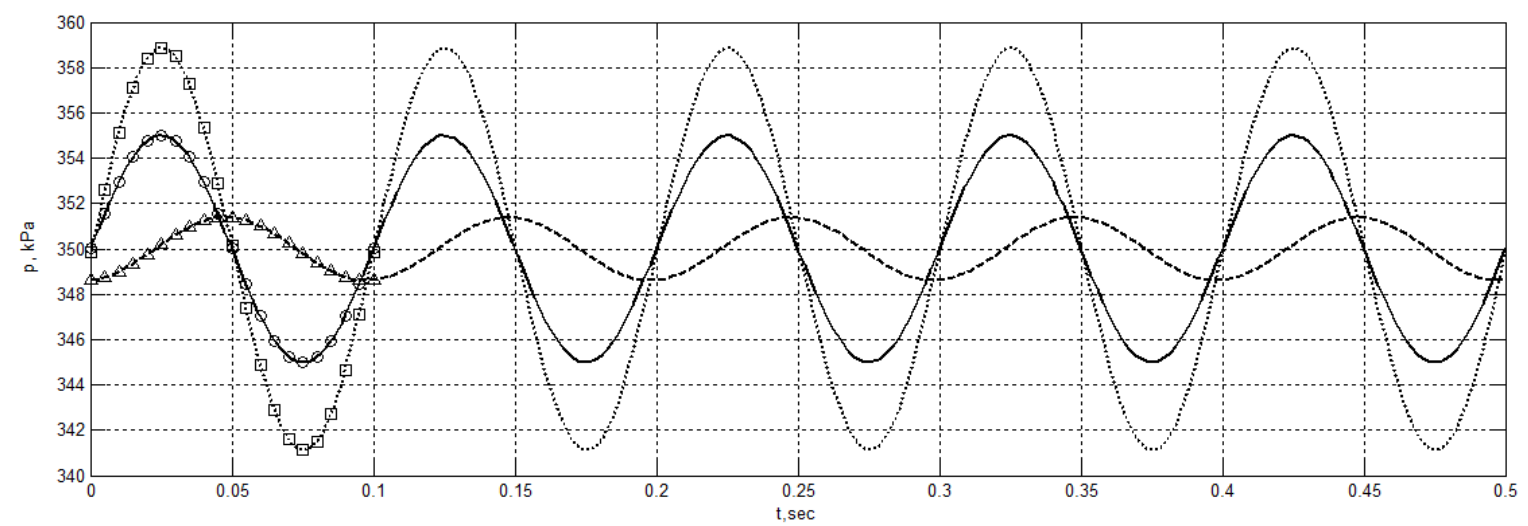

Fig. 8. Gas pressure oscillations: - $-\circ-$ in the upstream carrier ring of the orifice plate $\left(p_{i n}\right)$; $\cdots \cdot \square-$ pressure in the positive chamber of DPT $\left(p_{c h}\right) ;---\triangle-$ filtered signal of pressure $\left(p_{F}\right)$

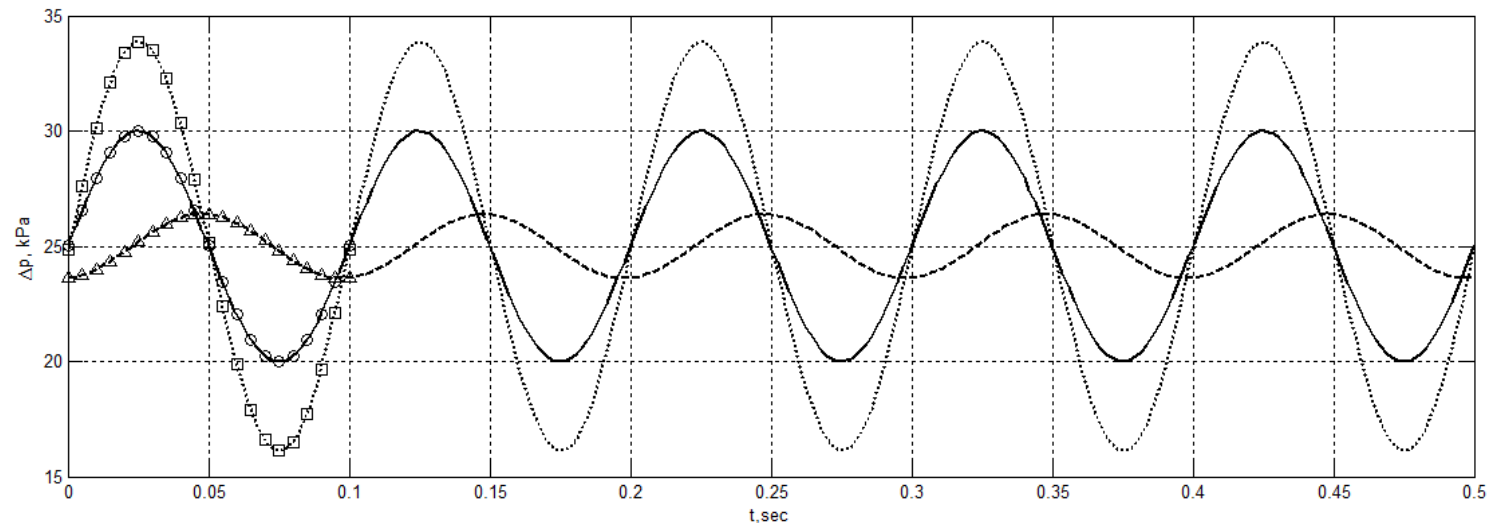

Fig. 9. Differential pressure oscillations: $-0-$ in the carrier rings of the orifice plate $\left(\Delta p_{i n}\right)$; $\cdots \square-$ in the chambers of DPT $\left(\Delta p_{c h}\right) ;---\triangle-$ filtered signal $\left(\Delta p_{F}\right)$

Table 3. Flowrate calculation results

\begin{tabular}{|c|c|c|c|c|c|c|c|c|c|}
\hline $\begin{array}{c}t, \\
\mathrm{msec}\end{array}$ & $\begin{array}{c}p_{i n}, \\
\mathrm{kPa}\end{array}$ & $\begin{array}{c}p_{c h}, \\
\mathrm{kPa}\end{array}$ & $\begin{array}{c}p_{F}, \\
\mathrm{kPa}\end{array}$ & $\begin{array}{c}\Delta p_{i n}, \\
\mathrm{kPa}\end{array}$ & $\begin{array}{c}\Delta p_{c h}, \\
\mathrm{kPa}\end{array}$ & $\begin{array}{c}\Delta p_{F}, \\
\mathrm{kPa}\end{array}$ & $\begin{array}{c}q_{s 1}, \mathrm{~m}^{3} / \mathrm{h} \\
(\text { at s.c. })\end{array}$ & $\begin{array}{c}q_{s 2}, \mathrm{~m}^{3} / \mathrm{h} \\
\text { (at s.c.) }\end{array}$ & $\begin{array}{c}q_{s 3}, \mathrm{~m}^{3} / \mathrm{h} \\
(\text { at s.c.) }\end{array}$ \\
\hline \hline 0 & 350.0 & 349.8 & 348.6 & 25.000 & 24.844 & 23.619 & 9713.3 & 9681.3 & 9432 \\
\hline 5 & 351.6 & 352.6 & 348.8 & 26.545 & 27.593 & 23.747 & 10020 & 10223 & 9459.4 \\
\hline 10 & 352.9 & 355.1 & 349.0 & 27.939 & 30.088 & 23.998 & 10288 & 10693 & 9510.1 \\
\hline 15 & 354.1 & 357.1 & 349.4 & 29.045 & 32.085 & 24.346 & 10500 & 11058 & 9581.9 \\
\hline 20 & 354.8 & 358.4 & 349.8 & 29.755 & 33.388 & 24.759 & 10632 & 11290 & 9665.4 \\
\hline 25 & 355.0 & 358.9 & 350.2 & 30.000 & 33.870 & 25.195 & 10677 & 11375 & 9752.5 \\
\hline 30 & 354.8 & 358.5 & 350.6 & 29.755 & 33.484 & 25.612 & 10632 & 11307 & 9835.4 \\
\hline 35 & 354.1 & 357.3 & 351.0 & 29.045 & 32.267 & 25.969 & 10500 & 11091 & 9906.8 \\
\hline 40 & 352.9 & 355.3 & 351.2 & 27.939 & 30.340 & 26.232 & 10288 & 10739 & 9957.7 \\
\hline 45 & 351.6 & 352.9 & 351.4 & 26.545 & 27.889 & 26.373 & 10020 & 10280 & 9986.3 \\
\hline 50 & 350.0 & 350.2 & 351.4 & 25.000 & 25.156 & 26.381 & 9713.3 & 9745.2 & 9987.7 \\
\hline 55 & 348.5 & 347.4 & 351.3 & 23.455 & 22.407 & 26.253 & 9399 & 9179.3 & 9963 \\
\hline 60 & 347.1 & 344.9 & 351.0 & 22.061 & 19.912 & 26.002 & 9106.6 & 8638.3 & 9912.8 \\
\hline 65 & 346.0 & 342.9 & 350.7 & 20.955 & 17.915 & 25.654 & 8868.8 & 8182.4 & 9844.6 \\
\hline 70 & 345.2 & 341.6 & 350.2 & 20.245 & 16.612 & 25.241 & 8711.8 & 7872.2 & 9761 \\
\hline 75 & 345.0 & 341.1 & 349.8 & 20.000 & 16.130 & 24.805 & 8658.1 & 7754.4 & 9674 \\
\hline 80 & 345.2 & 341.5 & 349.4 & 20.245 & 16.516 & 24.388 & 8711.8 & 7848.9 & 9589.8 \\
\hline 85 & 346.0 & 342.7 & 349.0 & 20.955 & 17.733 & 24.031 & 8868.8 & 8139.5 & 9516.4 \\
\hline 90 & 347.1 & 344.7 & 348.8 & 22.061 & 19.660 & 23.768 & 9106.6 & 8582.7 & 9463.4 \\
\hline 95 & 348.5 & 347.1 & 348.6 & 23.455 & 22.111 & 23.627 & 9399 & 9116.6 & 9433.5 \\
\hline 100 & 350.0 & 349.8 & 348.6 & 25.000 & 24.844 & 23.619 & 9713.3 & 9681.3 & 9432 \\
\hline
\end{tabular}




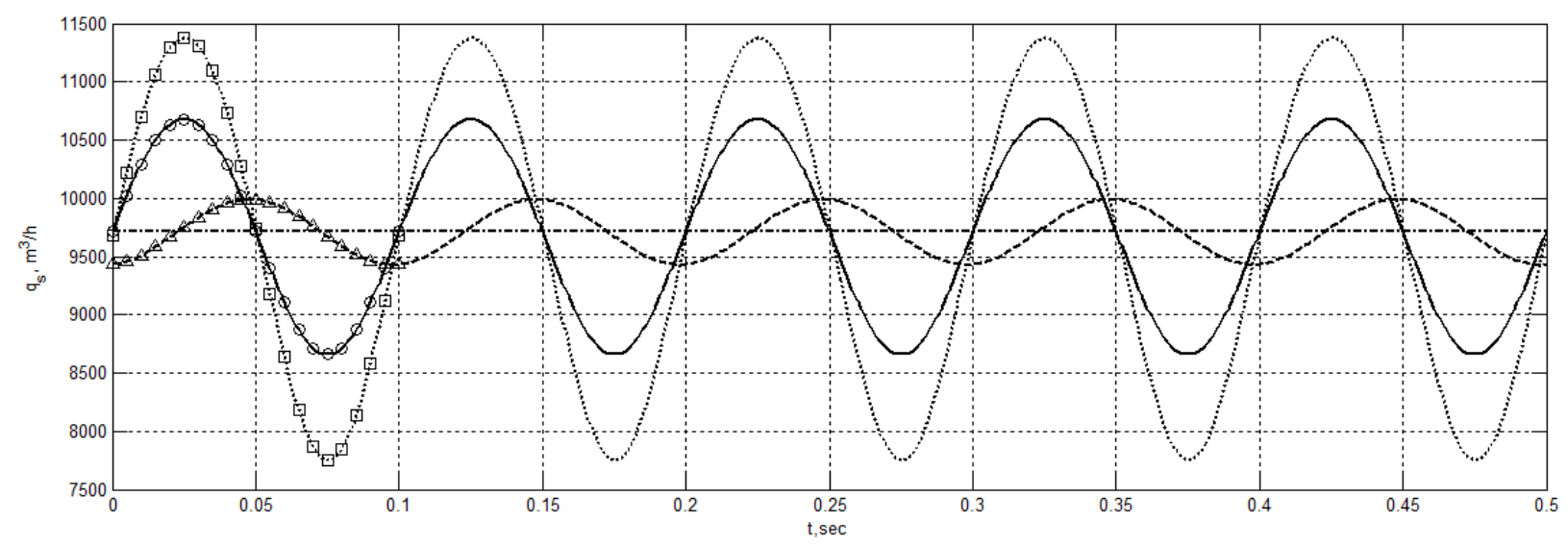

Fig. 10. Flowrate oscillations calculated on the basis of the pressure and the differential pressure signals: $-\circ-$ in the carrier rings of the orifice plate; $\cdots \cdot \square-$ in the chambers of DPT; --- $\triangle$ - filtered signals; -..-- average values of the pressure $(350 \mathrm{kPa})$ and the differential pressure $(25 \mathrm{kPa})$

The following notations are made in Table 3: $t$ is time; $p_{i n}$ is pressure in the upstream carrier ring of the orifice plate; $p_{c h}$ is pressure in the positive chamber of DPT; $p_{F}$ is the filtered signal of pressure; $\Delta p_{i n}$ is the differential pressure in the carrier rings of the orifice plate; $\Delta p_{c h}$ is the differential pressure in the chambers of DPT; $\Delta p_{F}$ is the filtered signal of the differential pressure; $q_{s 1}$ is flowrate calculated on the basis of $p_{i n}$ and $\Delta p_{i n} ; q_{s 2}$ is flowrate calculated on the basis of $p_{c h}$ and $\Delta p_{c h} ; q_{s 3}$ is flowrate calculated on the basis of $p_{F}$ and $\Delta p_{F}$.

The calculated values of flowrate were integrated in order to obtain the gas volume during the period of time of $1 \mathrm{~h}$ (see Table 4). We can see from the calculation results that the resonance in the ILs leads to the underestimation of the measured volume of gas since the volume $V_{2}$ is smaller than the volume $V_{1}$ by $0.52 \%$ (see Table 4 ). The volume $V_{1}$ was obtained by integration of flowrate $q_{s 1}$ calculated on the basis of pressure and differential pressure in the carrier rings $\left(p_{i n}\right.$ and $\left.\Delta p_{i n}\right)$. It is a reference volume of gas. The volume $V_{2}$ was obtained by integration of flowrate $q_{s 2}$ calculated on the basis of pressure and differential pressure in the chambers of DPT ( $p_{c h}$ and $\Delta p_{c h}$ ).

Filtration and averaging of the pressure and the differential pressure signals lead to overestimation of the measured volume of gas since the volumes $V_{3}$ and $V_{4}$ are bigger than the volume $V_{1}$ by approximately the same value $(0.2 \%)$. The volume $V_{3}$ was obtained by integration of flowrate $q_{s 3}$ calculated on the basis of the filtered signals of pressure and differential pressure $\left(p_{F}\right.$ and $\left.\Delta p_{F}\right)$. And the volume $V_{4}$ was obtained by integration of the constant flowrate calculated on the basis of the average values of pressure $(350 \mathrm{kPa})$ and differential pressure $(25 \mathrm{kPa})$.

Table 4. Gas volume calculation results

\begin{tabular}{|c|c|c|c|c|c|}
\hline & Name of parameter & Notification & $\begin{array}{c}\text { Value } \\
\left(\mathrm{m}^{3} \text { at s.c. }\right)\end{array}$ & $V_{i}-V_{1}$ & $\begin{array}{l}\left(V_{i}-V_{1}\right) / \\
V_{1} \cdot 100 \%\end{array}$ \\
\hline \multirow{4}{*}{$\begin{array}{l}\text { Gas volume based } \\
\text { on the flowrate } \\
\text { calculated for }\end{array}$} & $p_{\text {in }}$ and $\Delta p_{\text {in }}$ & $\overline{V_{1}}$ & 9690.74 & 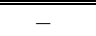 & 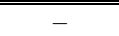 \\
\hline & $p_{c h}$ and $\Delta p_{c h}$ & $V_{2}$ & 9639.86 & -50.88 & -0.52 \\
\hline & $p_{F}$ and $\Delta p_{F}$ & $V_{3}$ & 9711.69 & +20.95 & +0.22 \\
\hline & average values of $p$ and $\Delta p$ & $V_{4}$ & 9713.3 & +22.56 & +0.23 \\
\hline
\end{tabular}

\section{Conclusions}

Based on the experimental and the theoretical investigation it was defined that the IL with the PT is an oscillating system where resonance phenomena may take place when there are pressure pulsations at the input of the IL. The mathematical model of IL with the PT was developed in order to carry out a qualitative and a quantitative study of influence of flow pulsations on the accuracy of flowrate and volume measurement. The developed model provides sufficient enough accuracy of simulation of transient processes since the maximum relative deviation of the simulated values from the experimental ones is $6.4 \%$.

After investigating the IL design it was found that for the low-frequency and medium-frequency pulsations it is better to apply the ILs of a small length and a big diameter. In this case the signal in the PT chamber will repeat the signal at the input of the IL. And for the high-frequency pulsations it is better to apply the ILs of a big length and a small diameter. This way the resonance will be avoided and the high-frequency signal will be filtered. 
Flow pulsation was simulated for an acting natural gas metering system with an orifice plate. Based on the calculation results it was defined that the resonance in ILs due to flow pulsation may cause an additional systematic error of gas volume measurement with a negative sign. Filtration and averaging of the pressure and the differential pressure signals may lead to an additional systematic error of gas volume measurement with a positive sign. The specific value of the additional systematic error depends on the parameters of the pulsating flow, design of ILs and chambers of PTs/DPTs. The systematic errors of gas flowrate and volume measurement caused by the flow pulsation can be reduced by choosing the correct design of the IL in order to avoid the resonance.

\title{
References
}

[1] Kostyk I. V., Matiko F. D. Investigation of Dynamic Characteristics of Impulse Lines of Pressure Measuring Transducers // Methods and devices for quality control. - 2014 - No. 1(32). - p. 83-92 (in Ukrainian).

[2] Fedoryshyn R. M., Hren, Y. V., Matiko F. D. Simulation of Dynamic Characteristics of Impulse Lines of Differential Pressure Flowmeters // Proc. of LPNU: Heat Power Engineering. Environmental Engineering. Automation. - 2009. - No. 659. - p. 73-78 (in Ukrainian).

[3] ISO/TR 3313:1998 Measurement of fluid flow in closed conduits - Guidelines on the effects of flow pulsations on flow-measurement instruments.

[4] Kremlevskiy P. P. Flow and Volume Meters: Reference Book. - 4th edition. - Leningrad. Mashynostroenie, 1989. - 701 p. (in Russian).

[5] DSTU GOST 8.586.5:2007 Measurement of Flowrate and Volume of Liquids and Gases by Means of the Standard Differential Pressure Devices. Part 5. Measurement Technique. - Kyiv. National Organization for Standardization in Ukraine (in Ukrainian).

[6] Kulinchenko V. R. Hydraulics, Hydraulic Machines and Drives: Text Book. Kyiv. "Inkos”, 2006. - 616 p. (in Ukrainian).

[7] GOST 30319.2-96 Natural Gas. Methods for Calculation of Physical Properties. Definition of the Compressibility Coefficient. (in Russian)

[8] Altshul A. D. Hydraulic Resistances. $-2^{\text {nd }}$ ed. Moscow, Nedra, 1982, 224 p. (in Russian).

[9] Pistun Y. P., Lesovoi L. V., Matiko F. D., Markovskyi D. I., Lesovoi R. L. "Raskhod-RU” CAD software. User Manual. Lviv. Publishing House of Institute of Energy Audit and Energy Carrier Accounting, 2007 - 127 p. (in Ukrainian).

\section{Дослідження точності витратомірів змінного перепаду тиску за наявності пульсацій потоку}

\author{
Роман Федоришин, Федір Матіко, Ігор Костик, Свген Пістун \\ Національний університет «Львівська політехніка», вул. С. Бандери, 12, Львів, 79013, Україна
}

\begin{abstract}
Анотація
Досліджено вплив пульсацій потоку на точність вимірювання витрати й об'єму природного газу за допомогою витратомірів змінного перепаду тиску. Подано результати експериментальних досліджень динамічних характеристик імпульсної трубки 3 вимірювальним перетворювачем тиску (ВПТ) із застосуванням високочастотного аналого-цифрового перетворювача сигналу тиску в камері ВПТ. Побудовано математичну модель імпульсної трубки з ВПТ, яка забезпечує дослідження їхніх динамічних характеристик 3 високою точністю. Виконано дослідження впливу конструктивних параметрів імпульсної трубки (довжина, діаметр) на іï динамічні та частотні характеристики, зокрема на значення резонансної частоти коливної системи (імпульсна трубка з камерою ВПТ). Для діючої системи обліку природного газу на базі методу змінного перепаду тиску виконано розрахунок та дослідження систематичних похибок вимірювання витрати та об'єму, зумовлених резонансом в імпульсних трубках, що викликаний пульсацією потоку. На основі розрахунків встановлено, що підсилення амплітуди коливань сигналу перепаду тиску внаслідок резонансу може призводити до виникнення систематичної похибки вимірювання об'єму газу від'ємного знаку. Систематичні похибки вимірювання витрати та об’єму газу, зумовлені пульсацією потоку, можуть бути зменшені, зокрема, за допомогою коректного вибору конструктивних характеристик імпульсних трубок для уникнення резонансу.
\end{abstract}

Ключові слова: витратомір; пульсації потоку; перетворювач тиску; природний газ. 